\title{
Urban Space and the Posthuman Imaginary
}

\section{Debra Benita Shaw}

\begin{abstract}
As the technologies which now largely determine what it means to be an embodied subject bring into doubt who 'we' thought we were, the world is becoming increasingly urbanised. What then is the relationship between the production of contemporary urban space and the new descriptions of bodies emerging from the biological sciences? What effect do new informational technologies have on how we conceive of cities and the way in which they are experienced? This chapter will explore the way that urban architectures and infrastructures have, since the nineteenth century, contributed to a cartography of exclusion and how 'posturban' cities of the twenty-first century have, under the terms of neoliberal capitalism, inherited and escalated these tendencies. The proposition will be that new paradigms of corporeality point the way to a posthuman politics which recognises the contingency of boundaries and requires the imagination of new urban forms and different modes of inhabitation.
\end{abstract}

In 2005, the Italian philosopher Giorgio Agamben gave a lecture in which he suggested that the processes of subjectivation in the contemporary city were becoming increasingly opaque. Currently, he suggested, we do not know enough about what he calls the 'the dispositif or group of dispositifs' which construct contemporary urban subjects. Here, he is following Michel Foucault in proposing that we need to understand how the deployment of institutionalised knowledges operates to determine the parameters of self-understanding but with a specific orientation towards what he calls 'metropolis': the city itself understood as a historically constituted apparatus of individuation. According to Agamben, we are lacking an analysis through which we may understand on what he calls the 'ontological or Spinozian level' how the processes which structure an attachment to a subjective identity affect individual agency. As he puts it, 'what, in the processes whereby a subject somehow becomes attached to a subjective identity, leads to a change, an increase or decrease in his/her power to act' (Agamben, 2005)? This chapter will address Agamben's question through an analysis of the historical conditions under which bodies and cities are produced as objects of study. What are the discourses that construct the dispositifs which determine the conditions for what or who has a right to the city? How does built space both reflect and perpetuate these ideas? How might this knowledge be applied to understanding urban subjectivities and their expression in the cartography of urban space?

At the dawn of late modernity, Le Corbusier was insisting that his contemporaries must 'measure afresh the consequences of being bodies', believing that architects must necessarily respond to a fundamental ontological change ushered in by the machine age which would require a substantial revision in concepts of inhabitation. As far as Le Corbusier was concerned, in fact, it was the job of the architect to respond to the changing conditions brought about by industrial technology and design an environment in which a 'new kind of consciousness' (Le Corbusier, 1964: 36) would flourish. In other words, he was proposing an architecture that would actively produce a citizenship adapted to the new relations of production. Thus, in what Donna J Haraway calls 'the social relations of science and technology' (Haraway 1991: 163), the built environment, as an expression of how these relations determine bodies and their right to inhabit urban space is of considerable importance. My proposal is that we should return to Le Corbusier's proposition that we should 'measure afresh the consequences of being bodies' under the new conditions ushered in by the 
information revolution. These conditions have not only provided for 'smart' cities and the interconnected culture of global capitalism but have forced us to re-evaluate what it means to 'be a body'. How then might we evaluate the effects of this at the level of everyday life? And, more importantly, how might this knowledge be applied to addressing the escalating inequalities of global cities in the third millennium?

\section{Modern Cartographies of Urban Space}

The organic body produced by the discourses of nineteenth and twentieth-century biological sciences knew its place. The hierarchical arrangement of species bequeathed by the work of Carolus Linnaeus in the eighteenth-century informed the development of social Darwinism through which emerged, not only taxonomies of human 'types' but a cartography of distribution which provided much of the justification for colonialism. The flâneur, Charles Baudelaire's Parisian stroller and observer of the everyday life of the city, 'botanizing on the asphalt' (Benjamin, 1999: J82a,3, 372), was a figure whose characteristic activity enabled this cartography to be brought home to the metropolis. He offered the assurance that the teeming life of the city could be mapped, classified and brought under calculative control (Frisby, 1994: 86). As Walter Benjamin astutely observed, he was both a detective and a journalist, able to read the text of the city, identify its characters and, through selling his findings to the newspapers, provide assurance to the bourgeois consumer of their superior position in the ranks of urban dwellers (Benjamin, 1999: M13a,2, 443 \& M16,4, 447).

A similarly hierarchical cartography can be seen to have informed the urban sociology of the Chicago School in the early twentieth-century. In general, the Chicago researchers understood the city as a 'pseudo-biological organism' (Soja, 2000: 86). In this model, the processes of urban life were conceived of as 'natural' and thus as amenable to scientific analysis as a rock pool. Many of the Chicago luminaries were influenced by the social Darwinism of William Graham Sumner (Parker, 2004: 40) whose famous dictum 'root, hog or die' (Bowler, 1983: 302) expressed his understanding of social competition as the process through which human improvement was to be realised. The Chicago method mapped the city as a series of hierarchically arranged zones distinguished by significant patterns of behaviour, levels of income and population density with movement through the zones conditioned by successful negotiation of the capitalist economy. Nineteenth-century organic metaphors applied to urban space provided the conditions under which this kind of scheme would make sense. The zones associated with the institutions of the state and the living arrangements of the bourgeoisie were correlated to the head or 'mind' of the city while the sewers and slums were associated with the organs of defecation and reproduction (Stallybrass and White, 1986: 145). Thus, the city produced as an idea through the conjoined discourses of bodily health and evolutionary biology could not only be diseased or infected but could be subjected to pseudomedical techniques of quarantine, purging and invasive surgery with the bodies that inhabit it assimilated to models of viral invasion and deformity. Schemes for 'cleansing' the city were thus developed on the basis of identifying, making visible and eliminating forms of life that were deemed not to meet the conditions for human flourishing.

Indeed, European and American cities in the late nineteenth and early twentieth centuries were the stages for exhibitions of colonised and enslaved peoples as exemplary not-quite humans; object lessons in the identification of deviant physicalities. The most famous cases were Saartje Baartman, known as the 'Hottentot Venus', who was paraded around Europe as an example of a supposed degenerate femininity (Gilman, 1985: 85) and Oto Benga, a Congolese pygmy who, in New York in 1906, was displayed in a cage with an orangutan (Sewell, 2009: 1). Late nineteenth century zoological gardens often exhibited whole villages of supposed 'primitives' whose behaviour was studied as examples of a less advanced stage of evolutionary development (Gilman, 1985: 110). 
These exhibitions performed segregation disguised as education, ensuring that people would monitor their fellow citizens for any taint of the 'primitive'. And, in the US, the so called 'ugly laws' explicitly prohibited persons whose performance of self did not conform to what was deemed normal from appearing on the streets until well into the late twentieth century. '[U]gly laws', writes Susan Schweik, 'are part of the story of segregation and profiling in the United States, part of the body of laws that specified who could be where, who would be isolated and excluded, who had to be watched, whose comfort mattered' (Schweik, 2009: 184). Thus a medical model in which a race and class derived pathology is marked on the body and backed by the authority of science can be seen to produce modern social space at the same time as it determines paradigms of subjectivity.

In view of this, it is worth considering the location of institutions concerned with the body and its health and education in urban space. If the display of colonised and enslaved peoples was to be effective in demonstrating racial distinctions, then the dominant population required standards through which they could measure degrees of deviation. The role of hospitals and museums, which are to be found in all cities, generally housed in architecturally significant buildings, is particularly interesting. These, as I will demonstrate, are not only institutions for the production and dissemination of knowledge but can be seen to deploy that knowledge as a mechanism for disciplining urban bodies. In the case of the modern hospital, this means both caring for the health of the population and educating them in the performance of what Zygmunt Bauman has called 'separating operations' (Bauman, 1992: 155). These are techniques of segregation and control designed to protect bodies from contamination at the same time as they institute standards of normality and abnormality, health and disease and acceptable and unacceptable behaviours.

Of course, Michel Foucault (2003) has written at length about classificatory medicine and the role of the hospital in the production and dissemination of medical discourse. But what I am interested in here is the specific architecture of hospitals, their siting within urban space and the way they function to impart a classificatory paradigm to the surrounding space. The separating operations which make sense in the case of infectious diseases or accumulations of dirt which may harbour harmful bacteria and in which, in modern cities, bodies are trained from birth have their origin in the topography of the hospital which was developed to both segregate hospital patients and subject them to regimes of medication and infection control. Similar techniques then contribute to the segregation of domestic space, 'localizing families (one to a house) and individuals (one to a room)'. As Foucault points out elsewhere, in nineteenth-century working-class housing estates, these arrangements ensured 'a sort of spontaneous policing or control' (Foucault, 2004: 251). At the same time, separating operations are practiced diligently in the home where they become the measure of 'good' and 'bad' parenting and, in the case of women, are associated with sexual hygiene and 'correct' performances of gender. For Bauman, these ideas find their symbolic expression in the consumption of cleaning technologies, 'brooms and brushes, soaps, cleaning sprays, washing powders' (Bauman 1992, 155). I would suggest they are further symbolised by the centrality of the kitchen in the design of the modern suburban home which functions to condition family life through food preparation and consumption. Indeed, the function of the 'ethnological' villages in nineteenthcentury zoological gardens was precisely to demonstrate a deviant domesticity to which bourgeois practices could be compared. More recently, kitchens have become the focus for anxieties about correct nutrition and the micromanagement of separating operations aimed at policing the behaviour of children. It is not difficult to see then how the hospital, as a representation of space (Lefebvre, 1991: 45), is involved in the structuring of urban subjects through a discourse of pathology which separates according to racialized norms of health expressed through performances of sexuality, gender and domesticity. 
Tony Bennett (1995) has made a study of the natural history museum which reveals with startling clarity how it, like the hospital, functions to structure both the surrounding space and the identification of bodies within it. Indeed, as he demonstrates, the architectural arrangements of nineteenth-century museums were specifically oriented towards making visible both the artefacts on display and the visiting public. While the artefacts were arranged sequentially to impart knowledge of biological evolution as progressive and racial hierarchies as natural, the visiting public and in particular the newly-admitted working class, were encouraged to conform to norms of deportment and behaviour commensurate with an educated, middle-class sensibility and to police both themselves and others accordingly. What this effected was an identification of self according to the established authority of the biological sciences alongside the training of the body in line with both a disciplinary architecture and an order of classificatory knowledge. This then can be seen to inculcate a form of performance in which the compensatory rituals of museum viewing are conflated with the determination of self in a taxonomic order. These rituals are then carried beyond the walls of the museum, serving to further establish the relationship between the organisation of space and the identification of natural kinds. This is what Barbara Kirshenblatt-Gimblett calls 'the museum effect'. '[U]rban dwellers such as James Boswell', she writes, 'reported that walking in the streets of London 1775 was "'a high entertainment of itself. I see a vast museum of all objects, and I think with a kind of wonder that I see it for nothing"' (Kirshenblatt-Gimblett, 1991: 410). Poor neighbourhoods were favoured by amateur ethnographers. Here, '[a]ny stranger could see openly on the streets what in better neighborhoods was hidden in an inaccessible domestic interior, in a closed carriage, or under layers of clothing' (Kirshenblatt-Gimblett, 1991: 411). The museum effect thus promotes a form of voyeurism in which the poorer neighbourhoods function to establish the success of separating operations in the production of bourgeois subjects. The 'natural history' of the city is established, made visible and ordered accordingly.

What is significant here then is the way in which the discourse of the biological sciences can be seen to construct the cartography of urban space and to order the city in terms of a progressive ideology. Natural history museums did not necessarily intend to promote social Darwinism but the effect of being exposed to a sequentially ordered reading of natural evolution in what amounts to a cathedral of knowledge should not be underestimated. The ugly laws, alongside the museum effect, can be seen to have established not only a hierarchy of acceptable and unacceptable bodies but to manage bourgeois concerns about (particularly racial) degeneration alongside what were deemed inappropriate expressions of sexuality. Indeed, sexual degeneracy was often equated with physiological distinctions which were 'discovered' to be prevalent among races thought to be less advanced in the 'great chain of being'. In this way, physical marks of degeneracy were established and the expulsion of the bodies bearing them from full participation in urban life could be justified by the authority of science and achieved through the kinds of mutual surveillance promoted in museum space.

What this amounts to is a constant sifting of bodies according to arbitrary and shifting standards of appearance, behaviour and deportment measured against an ideal which, fundamentally, does not exist. It is an axiom of feminist and post-colonial theory that the standards for full inclusion in the species category 'human' are determined by comparison with the white European male who remains both the arbiter of difference and the unmarked body from which all other bodies receive their marks of deviation. While this, in terms of cultural representations of race and gender, is undoubtedly true, what is also clear is that a central concern and perhaps the driving force of scientific modernity has been to define the qualifications for human belonging. The Holocaust, one of the most pernicious crimes of the last century, remains the quintessential example of the violence inherent in this project and the escalation of anxieties which have attended it. 
When, at the end of The Order of Things (1994), Foucault hopefully foresaw the death of 'Man', he was signalling the demise of an ontological concept mired in the economic imperialism of the capitalist world order that had been legitimated by the scientific method applied to populations and social structures. 'Man', however, was and always has been too indeterminate to pin under the objective lens, resulting in a series of approximations defined largely through invented categories of exclusion. 'Man' then, is not only an unmarked body but an empty category that successive descriptive iterations have struggled to fill. He is probably best represented by Vitruvian Man, the Roman ideal of the perfectly proportioned male body that, as imaged by Leonardo, is an annoyingly persistent figure, often used to represent a vaguely defined universal humanity but, in fact, representing nothing at all. Vitruvius's 'perfect' proportion is just that; an ideal that no body approximates, developed originally to illustrate the principles to be applied in the building of temples in ancient Rome. Vitruvian Man thus stands for both the transcendent promise of universal humanism and the idea which has conditioned the biopolitics of architecture. Hence Sven-Olov Wallenstein can claim that 'the trajectory of architectural modernity can be interpreted as ... a biopolitical instrument' (Wallenstein 2009, 4) the goal of which is to 'produce subjectivity' (Wallenstein 2009, 20, emphasis in original).

I have referred to hospitals and museums as examples of how this process is caught up with the discourse of the biological sciences. There are, of course, many others including, as I have suggested, the family home, a site of intense separating operations and a space that is still nominally private but is now thoroughly penetrated by surveillance in the interests of the child. As Roddey Reid has pointed out, "'family" and its liberal body have remained the very measure of the "human"' (Reid, 1995: 190). However, contemporary moral panics about inadequate parenting, particularly among the poor, can be seen to have escalated in concert with more recent uncertainties about the integrity of the bourgeois body so necessary to the maintenance of the family ideal. The irony here is that the biotechnologies that are the product of convergences between information technology and the biological sciences, designed originally to finally determine the essence of what it means to be human through techniques like genome sequencing, are not only casting doubt on where the human ends and other forms of life begin. Under the pressure of markets for, for instance, sophisticated anti-ageing technologies, bodies and machines are being brought into ever closer entanglement. At the same time, as my further discussion will demonstrate, the new social relations of science and technology are significantly impacting how urban space is understood.

\section{Posturban Production}

If the group of engineers and scientists collectively referred to as 'transhumanists' are to be believed, human bodies are a problem to be solved by technology. For them, the advent of the digital age and the drive towards general artificial intelligence implies only one thing - that we are in the process of producing our successor species. Their plan, articulated by organisations like Humanity+ (2016-17) is to speed the process towards the point where we become immaterial; where what we thought was human becomes something other - a discorporate mind which, in full realisation of the promise of enlightenment, need no longer fear the decay of the body and its end in death. There are various versions of the trajectory towards what Ray Kurzweil has called 'the singularity' (Roden, 2015: 22. Thorpe, 2016: 96), most involving harnessing human intelligence to vast digital networks, employing the so called NBIC technologies (nanotechnology, biotechnology, information technologies and cognitive science) to finally transcend corporeality and become something that we can currently not even imagine. The singularity describes the point where 'human' no longer applies to what we have become; where a new mode of being emerges, untethered from planet Earth. 
This is not science fiction but a significant and well-funded project, supported by both governments and major corporations in several (mostly Western) countries (Fuller, 2011). The questions that it raises, in the context of a volume devoted to urban imaginaries, are many. For transhumanists, presumably, the city, along with the body, will no longer be a problem. Urban living, in this case, is to be understood as a necessary historical development where the concentration of capital in industrial and, later, information technologies during the twentieth and twenty-first centuries has provided for the promise of techno-salvation. The injustices of advanced capitalism and their expression in urban deprivation can thus be understood as sacrifices on the road to enlightenment. Leaving aside the as yet unsolved problem of isolating the physical properties of mind in the hope that it can be replicated in a silicon environment, the fact remains that the ideology of transhumanism is concomitant with the anti-urbanism of capitalist elites who commute by helicopter to high-rise apartments to avoid contact with the contaminating street (Graham, 2016: 99).

Fear of the body here is paramount. If the unpredictability of the body can be dispensed with then fear of death - the one thing that wealth can never wholly guard against - is alleviated. At the same time, the promise is that the threat of other bodies, particularly the increasingly mobile and uncontrolled bodies of the poor and stateless, will no longer be a concern. Transhumanism aside, this is made explicit in the marketing of luxury housing developments which derive added value from their stringent security arrangements and self-contained facilities (Minton, 2017: 20 - 24). In a UK study completed in 2004 Rowland Atkinson and John Flint identified a series of 'corridors' in urban space through which urban elites commuted in regular journeys between luxury apartments, shopping and entertainment facilities and exclusive schools, immured in utility vehicles more suited to off-road competition than the school run (Atkinson and Flint, 2004: 888). The 'danger' that is implied here and that must be avoided at all costs is the lived urban reality of the majority of the population. Like the world in 2019 as imagined in Ridley Scott's celebrated Blade Runner (1982/92/2007), cities are experienced as polluted by both the environmental effects of capitalism and its human and technological discards. Migration to the 'off-world colonies' may not yet be possible but the Transhumanist Declaration (Humanity+, 2016-17) includes a commitment to extraterrestrial migration alongside the technological 'enhancements' that will usher in a new form of life that transcends both the urban and human condition.

This then is one type of urban imaginary for the twenty-first century and it is one that owes much to the discourse of urban lawlessness inaugurated during the early years of the industrial revolution, based in racial and class-based anxieties and perpetuated throughout the growth of industrial and, later, consumer capitalism. Indeed, it is a discourse that has accompanied and largely structured the growth of the modern city and its institutions. It is a discourse, therefore, that achieves its effects through the dissemination of specific knowledges in urban space, marked by the architectonics of urban design. In other words, what I am suggesting is that urban architecture and design does not respond to a need for protection against the inherent violence of urban life but actively perpetuates it.

Furthermore, cognitive cartographies of urban space are increasingly communicated through screen based media which reproduce the voyeurism of the museum effect through 'gritty' drama and 'reality' television, often juxtaposed with breath-taking views of the cityscape, making clear the separation between the city as an 'experience' and as actually lived. This contributes significantly to what Sarah Chaplin and Eric Holding describe as the 'posturban' city, where urban space is produced as a facsimile of itself as developers respond to the fiscal demands of tourism and commerce rather than the needs of its inhabitants (Chaplin and Holding, 2002). The marketing of cities through their representations on film and video, in digital gaming and advertising, as well as the staging of mega- 
events like the Olympics contributes to a culture of urban cleansing in a drive to force cities, and the bodies that inhabit them, to correspond to their imaginary equivalents. In fact, it is probably not too much of a stretch to claim that cities become their imaginary equivalents to the extent that the removal of bodies that are out of place in the scheme can not only be justified but effected through architectural design as well as the kinds of draconian policing that has led to the disproportionate number of deaths of young black men at the hands of law enforcement officers in both the US and the UK (Townsend, 2017). In London, the politics of austerity combined with the sale of social housing sites to private developers has resulted in the displacement of people on low incomes to satellite towns, often miles from their work and their extended families (Minton, 2017: 81 - 94).

This then is part of the process that Mike Davis calls 'imagineered urbanism' (Davis, 2007: 51) in which cities are engineered to appeal to what Anna Minton calls 'Big Capital' (2017). This, in turn, provides for a sorting of bodies according to how closely they conform to the codes of behaviour and appearance that the new imagineered spaces demand. In twenty-first century global cities private spaces which look like public spaces have proliferated (parks and squares for instance). Here property law determines rules of access, rather than local ordinances. At the same time, new forms of heterotopia have emerged in the networked spaces of social media where everyday life is codified in terms of the spectacle and urban space is experienced solely through the cartographies of tourism and consumption. To give just one example, popular tourist hotels now provide 'selfie spots' where tourists are able to locate themselves strategically in the frame with a notable landmark (Dinhopl and Gretzel 2016: 136). 'Tourists', write Anja Dinhopl and Ulrike Gretzel, 'are ... not looking through the screen at the destination, but at the screen to see themselves' (2016: 132). Shared and networked in real time, these are visual affirmations of the posturban subject, confirming emplaced prosumer identities at the same time as they enhance the spectacle.

This then goes some way towards answering Agamben's question. The group of dispositifs that constructed the modern industrial subject now emerge as techniques to contain the anxieties unleashed by the effects of urban living in the context of colonialism. The 'botanising' project of the flâneur, the museum effect and the ugly laws are examples of how urban culture has evolved as an expression of these anxieties enacted through the control of bodies and their movements, informed by the discourses of the biological sciences. In the contemporary city, advanced capitalism has worked on the desire for knowledge of others as a means to define the self and thus has constructed the posturban in a realm beyond the street and its connection to lived reality. Imagineered urbanism is built for consumption and sold on the basis of disconnection from what threatens the integrity of the self, the body, the family and, ultimately, the imagined community (Anderson, 1983) of the nation state. Transhumanism is this disconnection fully realised; a conflation of the discourses of the medical sciences with the 'exiling of ... powers in a "world beyond"' (Debord 1995, 18) identified by Guy Debord as the 'religion' of the capitalist spectacle. Agency, in the contemporary metropolis, is thus conferred by successful separation from the life of the city, from the corporeality of other bodies and thus from anything that might be recognised as community.

The posturban, in fact, confers a dual ontology. Considering the late twentieth century migration of the flâneur to cyberspace, Kristin Veel (2003) offers a helpful distinction between labyrinth viewers and labyrinth walkers where the ideal is to be both; to both inhabit the city and take advantage of the overview perspective offered by information and communications technologies - Google Earth, drone mounted cameras and video games like Grand Theft Auto (Rockstar Games) which offers the frisson of engagement with the street but with the safety controls firmly on. The reality is that imagineered urbanism offers monied elites a permanent exile in a pay-per-view utopia where the promise of these technologies is realised while labyrinth walkers remain as unpaid extras in a movie 
of their own lives. Witness the vast displacement of urban dwellers in cities where the Olympics have been staged. Olympic stadia, in fact, are the new architecture of separation, staging a spectacle of elite bodies whose characteristic modes of performance are emulated in everyday life. Monitoring here is through, again, informational devices which measure something called 'health' as a quantity of steps, heartbeats and calories. The function of the hospital as a 'curing machine' which not only attends to sick bodies but inculcates disciplinary regimes has been digitized, miniaturized and returned to the body as wearable technology.

Hardly surprising then that Matthew Gandy refers to 'cyborg urbanization' to describe the way in which 'the distinction between 'city' and 'non-city' becomes extensively blurred ... to produce a tendential landscape exhibiting different forms of integration between the body, technology and social practices' $(2005,41)$. Cyborg urbanization is an effect of post-industrial capitalism at work on the interrelation between urban infrastructures and urban subjects but, equally, as I have suggested and as Gandy also points out, it does not represent a break with the trajectory of nineteenth-century modernity but is its realisation in a new space which may be virtual but leaves nothing of the material of the city untouched. Cyborg urbanization then is one result of the profound changes in the social relations of science and technology brought about by the information revolution. It suggests that we might want to revise how we understand from what and into what we might be evolving and embrace a hybrid ontology in which the perfection of a putative ideal makes no sense. Nevertheless, despite this, as Rosi Braidotti puts it, 'Vitruvian Man rises over and over again from his ashes, continues to uphold universal standards and to exercise a fatal attraction' (Braidotti 2013, 29). In other words, the conditions exist through which new forms of subjectivity might be realised but the only future on offer seems to be based in the destruction of what we are for the sake of something we can never be. This was what Haraway was referring to when she offered the cyborg as a figure in which socialist-feminists of the late twentieth century might recognise themselves, in opposition to the nature-identified feminine subject, derived from the gendered suppositions of the seventeenth-century natural philosophers (Easlea, 1981) of much 1980s feminist discourse. Hence, I want to conclude here by offering some brief suggestions for how actively rejecting the human as a circumscribed category, and embracing a cyborg ontology, fully at home in the posturban and attuned to its as yet unrecognised potential, might free us to act effectively for a more egalitarian city.

\section{Posthuman Urbanism}

That Haraway's argument has had major effects beyond its original constituency is testament to its potency in identifying the conditions for subject formation in general under the terms of informational capitalism and its attendant social structures. The cyborg is a figure for a posthuman world in which the biological sciences are increasingly focused on making bodies rather than describing them (Cooper, 2008) and the discourse of the informational sciences is becoming increasingly pervasive in the codes which describe life and the processes through which it is realised. Equally it is a figure which makes sense of the everyday under the terms of cyborg urbanization and codes strategies for political organising which take advantage of the way in which it does violence to the fixed determinations of space guaranteed by Vitruvian Man. Le Corbusier could dream an architecture which would both shape and accommodate bodies fully adapted to the necessary social conditions to realise the promise of modernity but what might it mean to dream an architecture for bodies that, as Haraway says, do not 'end at the skin' (Haraway, 1991: 178)? Or, perhaps more pertinently, what might be the consequences of accepting ourselves as always already posthuman; as having evolved with the technologies which have shaped our worlds and conditioned our ontology (Stiegler 1994, 2009)? At the very least it instructs us that the divide between nature and 
culture is meaningless and that, where there are no natural beings there are equally no predetermined forms or hierarchical taxonomies which structure the relation between bodies and space. Accepted divisions of gender, race, class, sexuality and, more specifically, species emerge as arbitrary and open to challenge. Beyond this, the posthuman idea violates the sanctity of the institutions which have traditionally served the human ideal and have been largely responsible for its perpetuation. The isolated domesticity of the modern family and its association with private property, inherited wealth and sanctioned reproduction, already under threat, begins to look distinctly alien to beings no longer invested in policing biological boundaries.

I do not mean to propose here a new architecture for posthumans or indeed a new form of urban planning. Tearing down and re-building, as accomplished by Baron von Haussmann in nineteenth century Paris and, more recently, the 'neo-Haussmanization' (Merrifield, 2014: xii) of global cities which makes imagineered urbanism a reality is, after all, not only labour and resource intensive but what continues to create and maintain urban hierarchies and divisive living conditions. My proposition is for a form of urban imaginary through which a posthuman politics can be realised which re-imagines and re-purposes what exists; which employs the kinds of aesthetics suggested by sampling and the ethics of code hacking. That is, it makes use of the morphological plasticity imparted to urban space by global information flows and the churn of market demand to, as Braidotti puts it 'mobiliz[e] resources and visions that have been left untapped and ... actualiz[e] them in daily practices of interconnection with others' (Braidotti, 2013, 191). Some of these practices already exist; others are yet to be invented.

Squatting, for instance, is a practice as old as private property which lends itself to protean reinvention under changing conditions (Vasudevan, 2017). The 'movement of the squares' was essentially a series of squatter camps which, beginning with the 2011 occupation of Tahrir Square in Cairo, spread globally over the following three to five years (Gerbaudo, 2017). This was not squatting to alleviate homelessness (although it drew attention to the displacements effected by neoliberal capitalism) but an imposition of bodies in the spaces of the city where visibility is guaranteed which was co-ordinated, for the most part, by social media. It may, with hindsight, be understood as an expression of a nascent posthuman politics and not only because it depended on the co-presence of individuals simultaneously in urban space and the space of digital networks.

The fact that many cities have squares at all is a legacy of the Roman camp with its grid pattern determining a strict hierarchy of position and place (Betsky, 1995: 46). The central square was at the crossing of two major roads and was left deliberately empty. It thus provided an absent centre which conditioned all the surrounding space and guaranteed its order. This then, can be understood as the space of Vitruvian man, representing the human ideal which real bodies can only ever approximate. Making home in this space, even if only temporarily, establishes the everyday in the heart of institutionalised space, challenges the human paradigm which keeps bodies in their ideologically allotted place and confounds the separating operations effected by social architecture. Similarly, practices like parkour, which originated in the Paris banlieues and makes use of the verticality of city architecture to defy the restrictions of travel through the city at street level, and Urban Exploration in which groups of practitioners delve into the world beneath the street and party in the spaces abandoned by urban 'renewal' (Garrett, 2013) are glimpses of a nascent re-imagining of the city which defies the shepherding of bodies according to the dictates of imposed posturban cartographies. These practices have in common the deployment of advanced visual technologies and the use of social media through which the experience is communicated to a wider community. They can, in fact, be understood as new forms of psychogeography which utilise the media of imagineered urbanism to defy the conditioning of bodies according to its spatial determinants. 
Psychogeography, as employed by the Situationist International in the mid twentieth century, was a mode of navigating the city intended to disrupt the imposed cognitive cartography of the worker under capital through creative meanders; to discover 'a new city via a calculated drifting (dérive) through the old' (Wark, 2015: 17). This much misunderstood practice was pitted against the 'rational' city of planners and architects like Le Corbusier. Crucially, the dérive was a conscious interposition of the unruly body in the managed spaces of the modern city and a deliberate attempt to demonstrate how 'a new form of consciousness' could indeed flourish under the conditions of consumer capitalism. This was a revolutionary consciousness attuned to the potential for creative play in the interstices of the metropolis rather than, as Le Corbusier had intended, one suited to the progressive ideals of modernity.

For Stevphen Shukaitis, psychogeography gains new potential under postindustrial conditions where 'the shaping of the city is embedded directly within the changing circuits of capital accumulation' (Shukaitis, 2016: 56). This is the posturban as constructed through immaterial labour; where the tourists employing selfie spots to accumulate images to post on social media produce the imagineered city even as they consume it. In light of this, practices which defy the strategic locating of bodies in urban space to optimise revenue flows under the guise of providing 'experiences' and 'consumer choice' have the potential to re-shape the city, particularly if they simultaneously expose how the maintenance of the posturban surface also relies on what Keller Easterling calls 'infrastructure space' (Easterling, 2014: 13). This is the space which comprises the technologies which reproduce the posturban in diverse global conditions; networked computing facilitated by fibre optic cables deep under the city and images fed to the networks by satellites high above which also facilitate surveillance and remote war. Ironically perhaps, they are also the technologies which have enabled doubt to be cast on the integrity of the organic body and have ushered in the possibility of a posthuman orientation towards the materiality of bodies and their effects in urban space.

Bradley Garrett describes Urban Explorers as 'documenting archaeologies of the future' (2013: 129) when they unearth and photograph the remains of bankrupt businesses, failed building projects and other decaying pockets of urban life which have escaped, however briefly, the overarching dominance of the spectacle. Here he is echoing Fredric Jameson's re-working of Utopia to emphasise how its futurity can be built out of the 'imaginary enclave[s]' which are 'aberrant by-product[s]' of the continual differentiations which historically produce social space (Jameson, 2005: 15). But I want to suggest here that it could equally apply to the sense in which a posthuman politics does not presuppose either the body or the space appropriate to it. Urban exploration, in common with parkour, is a mis-use of urban monuments (Lamb, 2014); a psychogeography which deliberately defies the biopolitics inherent in the Vitruvian paradigm. We may not yet know what posthuman bodies can achieve but we can make use of the new imaginaries which the idea of posthuman selves makes possible to subvert the architectonics of the city and re-invent the conditions of everyday life.

\section{Works Cited}

Agamben G (2005) Metropolis. Transcribed and translated by Arianna Bove. Available at http://www.generation-online.org/p/fpagamben4.htm. Accessed 25/09/17

Anderson B (1983) Imagined Communities: Reflections on the Origin and Spread of Nationalism. London and New York: Verso.

Atkinson R and Flint J (2004) Fortress UK? Gated Communities, the Spatial Revolt of the Elites and Time-Space Trajectories of Segregation. Housing Studies 19(6): 875-92. 
Bauman Z (1992) Mortality, Immortality \& Other Life Strategies. Oxford and Cambridge: Polity.

Benjamin W (1999) The Arcades Project. Translated by Howard Eiland and Kevin McLaughlin.

Cambridge, MA, and London: The Belknap Press of Harvard University Press.

Bennett T (1995) The Birth of the Museum: History, Theory, Politics. London and New York:

Routledge

Betsky A (1995) Building Sex: Men, Women, Architecture and the Construction of Sexuality. New York: William Morrow \& Co.

Bowler PJ (1983) Evolution: The History of an Idea. Berkeley, Los Angeles and London: University of California Press.

Braidotti R (2013) The Posthuman. Cambridge (UK) and Malden, MA: Polity Press.

Chaplin S and Holding E (2002) Addressing the Post-urban: Los Angeles, Las Vegas, New York. In: Leach N (ed.) The Hieroglyphics of Space: Reading \& Experiencing the Modern Metropolis. London and New York: Routledge, 185-99.

Cooper Melinda (2008) Life as Surplus: Biotechnology and Capitalism in the Neoliberal Era. Seattle: University of Washington Press.

Davis Mike (2007) Sand, Fear and Money in Dubai. In: Davis M and Monk D B Evil Paradises:

Dreamworlds of Neoliberalism. New York and London: The New Press, 48-68.

Debord G (1995/1967) The Society of the Spectacle. Translated by Donald Nicholson-Smith. New York: Zone Books.

Dinhopl A and Gretzel U (2016) Selfie-Taking as Touristic Looking. Annals of Tourism Research 57: 126-39.

Easlea Brian (1981) Science and Sexual Oppression. London: George Weidenfeld \& Nicholson.

Easterling, K (2014) Extrastatecraft: The Power of Infrastructure Space. London \& New York: Verso.

Foucault M (1994/1967) The Order of Things: An Archaeology of the Human Sciences. New York: Vintage Books.

Foucault M (2003/1963) The Birth of the Clinic. London and New York: Routledge.

Foucault M (2004) Society Must Be Defended: Lectures at the Collège de France 1975-76. Translated by David Macey. Harmondsworth, Middlesex, UK: Penguin Books.

Frisby D (1994) The Flâneur in Social Theory. In: Tester K (ed.) The Flâneur. London and New York: Routledge, 81-110.

Fuller S (2011) Humanity 2.0: What It Means to Be Human Past, Present and Future. Houndmills, Basingstoke, Hampshire, UK, and New York: Palgrave

Gandy M (2005) Cyborg Urbanization: Complexity and Monstrosity in the Contemporary City. International Journal of Urban and Regional Research 29(1): 26-49.

Garrett BL (2013) Explore Everything: Place-Hacking the City. London and New York: Verso

Gerbaudo P (2017) The Mask and the Flag: Populism, Citizenism and Global Protest. London: Hurst \& Co. 
Gilman SL (1985) Difference and Pathology: Stereotypes of Sexuality, Race, and Madness. Ithaca and London: Cornell University Press.

Graham S (2016) Vertical: The City from Satellites to Bunkers. London and New York: Verso.

Haraway DJ (1991) Simians, Cyborgs, and Women: The Reinvention of Nature. London: Free Association Books.

Humanity+. (2016-17). Transhumanist Declaration. Available

at http://humanityplus.org/philosophy/transhumanist-declaration/. Accessed 20/09/17

Jameson, F (2005) Archaeologies of the Future: The Desire Called Utopia and Other Science Fictions. London \& New York: Verso.

Kirshenblatt-Gimblett B (1991) Objects of Ethnography. In: Karp I and Lavine SD (eds.) Exhibiting

Cultures: The Poetics and Politics of Museum Display. Washington, DC, and London: Smithsonian Institution Press, 386-43.

Lamb, M.D (2014) Misuse of the Monument: The Art of Parkour and the Discursive Limits of a Disciplinary Architecture. Journal of Urban Cultural Studies, 1:1: 107-126. doi:

10.1386/jucs.1.1.107_1. Accessed 22/11/17

Le Corbusier (1964/1933) The Radiant City. London: Faber \& Faber.

Lefebvre H (1991/1974) The Production of Space. Translated by Donald Nicholson-Smith. Malden, MA, Oxford, UK and Carlton: Blackwell.

Merrifield A (2014) The New Urban Question. London: Pluto.

Minton A (2017) Big Capital: Who is London For? Penguin Random House.

Parker S (2004) Urban Theory and the Urban Experience: Encountering the City. London and New York: Routledge.

Reid R (1995) "Death of the Family": Or, Keeping Human Beings Human. In: Halberstam J and Livingston I (eds.) Posthuman Bodies. Bloomington and Indianapolis: Indiana University Press, 17799.

Roden D (2015) Posthuman Life: Philosophy at the Edge of the Human. London and New York: Routledge.

Scott, R (dir.) (1982/92/2007) Blade Runner. The Ladd Company, Shaw Bros., Warner Bros.

Schweik SM (2009) The Ugly Laws: Disability in Public. New York and London: New York University Press.

Sewell D (2009) The Political Gene: How Darwin's Ideas Changed Politics. London, Basingstoke and Oxford: Picador

Shukaitis, S (2016) The Composition of Movements to Come: Aesthetics and Cultural Labor After the Avant-Garde. London: Rowman \& Littlefield International.

Soja EW (2000) Postmetropolis: Critical Studies of Cities and Regions. Malden, MA, and Oxford: Blackwell.

Stallybrass P and White A (1986) The Politics and Poetics of Transgression. London: Methuen. 
Stiegler B (2009) Technics and Time, 2: Disorientation. Translated by Stephen Barker. Stanford: Stanford University Press.

Stiegler Bernard (1994) Technics and Time, 1: The Fault of Epimetheus. Translated by Richard Beardsworth \& George Collins. Stanford: Stanford University Press.

Swaine J and McCarthy K (2017) Young black men again faced highest rate of US police killings in 2016. The Guardian, 8 January, https://www.theguardian.com/us-news/2017/jan/08/the-countedpolice-killings-2016-young-black-men. Accessed 20/09/17

Thorpe C (2016) Necroculture. New York: Palgrave Macmillan.

Townsend M (2017) Deaths of black men in custody pose challenge on 'Stephen Lawrence level'. The Guardian, 3 September, https://www.theguardian.com/uk-news/2017/sep/03/police-custodydeaths-black-men. Accessed 20/09/17

Vasudevan A (2017) The Autonomous City: A History of Urban Squatting. London and New York: Verso.

Veel K (2003) The Irreducibility of Space: Labyrinths, Cities, Cyberspace. Diacritics 33(3/4): 151-72.

Wark, M (2015) The Beach Beneath the Street: The Everyday Life and Glorious Times of the Situationist International. London \& New York: Verso.

Wallenstein S-O (2009) Bio-Politics and the Emergence of Modern Architecture. New York: Columbia University and Princeton Architectural Press 